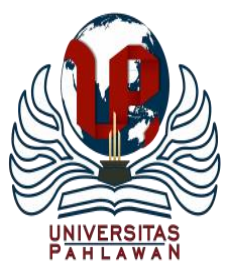

Jurnal Abdidas Volume 2 Nomor 1 Tahun 2021 Halaman 48-52

JURNAL ABDIDAS

http://abdidas.org/index.php/abdidas

\title{
Upaya Menurunkan Angka Kematian Ibu Melalui Peningkatan Kesehatan Ibu Hamil dan Kesehatan Reproduksi
}

\author{
Mardiana Ahmad ${ }^{1 凶}$, Patmahwati $^{2}$, Sharvianty Arifuddin ${ }^{3}$, Andi Asadul Islam ${ }^{4}$ \\ Prodi S2 Ilmu Kebidanan, Program Pascasarjana, Universitas Hasanuddin, Indonesia ${ }^{1,2,3,4}$ \\ E-mail:mardianaahmad@pasca.unhas.ac.id ${ }^{1}$ patmapadri85@gmail.com ${ }^{2} \underline{\text { sharviantyspog@gmail.com }}^{3}$ \\ andiasadul@yahoo.com ${ }^{4}$
}

\begin{abstract}
Abstrak
Program KB, penyuluhan dan penelitian dalam kelas antenatal merupakan salah satu program upaya pencegahan 3 terlalu dan 4 terlambat dan upaya menurunkan angka kematian ibu. Adapun tujuan dari pemberian konseling dan pelayanan KB yang bertujuan meningkatkan pengetahuan dan mampu menyikapi permasalahan yang berhubungan dengan kehamilan dan persalinan yang bertujuan untuk menurunkan angka kematian ibu. Sasaran dalam kegiatan ini adalah ibu hamil, pasangan usia subur di Desa Leang-Leang Kabupaten Maros dengan peserta pemasangan IUD sebanyak 12 orang dan peserta penyuluhan 57 orang. Metode yamg digunakan adalah penyuluhan melalui ceramah dengan menggunakan media reaflek, demonsterasi dan laptop. Kegiatan ini dilakukan untuk meningkatkan kualitas kesehatan ibu hamil dan pasangan usia subur khususnya dalam bidang keluarga berencana dan pendidikan di wilayahnya secara mandiri.
\end{abstract}

Kata kunci : kesehatan reproduksi, keluarga berencana

\begin{abstract}
The family planning program, counseling and research in the antenatal class is one of the programs for preventing and an effort to reduce maternal mortality. The purpose of providing family planning counseling and services is aimed at increasing knowledge and being able to respond to problems related to pregnancy and childbirth which aim to reduce maternal mortality. The targets of this activity are pregnant women, fertile aged couples in Leang-Leang Village, Maros Regency, with 12 IUD installation participants and 57 extension participants. The method used is counseling through lectures using reaflek media, demonstrations and laptops. This activity is carried out to improve the health quality of pregnant women and couples of childbearing age, especially in the field of family planning and education in their respective regions.
\end{abstract}

Keywords: reproductive health, family planning

Copyright (c) 2021 Mardiana Ahmad, Patmahwati, Sharvianty Arifuddin, Andi Asadul Islam

$\triangle$ Corresponding author

Address : Universitas Hasanuddin

Email : mardianaahmad@pasca.unhas.ac.id

DOI : https://doi.org/10.31004/abdidas.v2i1.195

ISSN 2721- 9224 (Media Cetak)

ISSN 2721- 9216 (Media Online) 


\section{PENDAHULUAN}

Angka kematian dan kesakitan ibu sebagai akibat dari proses kehamilan dan kelahiran saat ini masih sangat tinggi. Indonesia merupakan negara dengan survei tertinggi dalam kasus kematian ibu (AKI). Berdasarkan Survei Demografi Kesehatan Ibu (SDKI). Angka kematian per 100.000 kelahiran hidup menurun secara bertahan dari 390 (1991) menjadi 334 (1997),307 (2003) dan 228 (2007), kemudian pada tahun 2012 melonjak menjadi 359 per 100.000 kelahiran hidup (Sri \& Mubarokah, 2018).

Beberapa faktor kegagalan penurunan AKI di Indonesia adalah 3 terlambat (Terlambat mengambil keputusan, terlambat sampai di tempat persalinan, terlambat mendapat pertolongan dan 4 terlalu (terlalu tua, terlalu muda, terlalu banyak dan terlalu rapat jarak kelahirannya). Hal ini disebabkan oleh faktor budaya, politik, geografis dan faktor medis. Menurut Direktorat Kesehatan Ibu Kemenkes (2013) faktor penyebab langsung kematian ibu paling dominan adalah lain-lain (40,8\%); perdarahan (30,3\%); hipertensi $(27,1 \%)$; Infeksi (3,7\%) (Desa, 2016).

Bidan memiliki peranan dalam penanggulangan AKI karena bidan merupakan ujung tombak dalam pembangunan keluarga sejahtera dari sudut pemberdayaan dan pelayanan kesehatan dasar (Nurjasmi, 2020). Bidan memberikan asuhan yang berkualitas, pendidikan kesehatan yang sesuai dengan kondisi budaya serta bersifat menyeluruh di masyarakat untuk peningkatan kehidupan keluarga yang sehat, perencanaan kehamilan dan kesiapan menjadi orang tua (Yuningsih, 2016).
Beberapa program yang dilakukan melalui program $\mathrm{KB}$, penyuluhan,dan pendidikan dalam kelas antenatal. Program ini merupakan salah satu upaya pencegahan 3 terlalu dan 4 terlambat. Pemberian konseling dan pelayanan KB dilakukan untuk mempersiapkan keluarga yang lebih berkualitas, sejahtera, sehat maju, mandir, memiliki jumlah anak ideal, berwawasan kedepan. Adapun yang bertujuan meningkatkan pengetahuan dan mampu menyikapi permasalahan yang berhubungan dengan kehamilan dan persalinan. Kegiatannya antara lain sosialisasi Keluarga Berencana ( et al., 2016).

Mahasiswa Pascasarjana Kebidanan yang merupakan generasi penerus sekaligus elemen intelektual dan masyarakat adalah salah satu pihak yang turut mengemban amanah untuk pembangunan bangsa. Untuk melaksanakan Tri Darma Perguruan Tinggi,yaitu pengabdian masyarakat, mahasiswa magister kebidanan bekerjasama dengan masyarakat sehat melalui kegiatan pemeriksaan kelas antenatal dan sosialisasi keluarga berencana.

Upaya diatas merupakan salah satu strategi untuk menciptakan kesadaran ibu untuk hidup sehat,dan sekaligusmeningkatkan pengetahuan dan keterampilan ,tentang kehamilan, persalinan, perawatan nifas dan bayi baru lahir,sehingga dengan pengetahuan yang dimiliki mereka mampu mampu merubah sikap dan perilaku menjadi ibu yang berkualitas (Sri \& Mubarokah, 2018).

\section{METODE}

Pelaksanaan pengabdian ini berupa sosialisasi tentang keluarga berencana. Metode 
yamg digunakan adalah penyuluhan melalui ceramah dengan menggunakan media reaflek, demonsterasi dan laptop. Kegiatan ini dilakukan pada bulan November 2017 di Kelurahan Kelurahan Leang-Leang Kecamatan Bantimurung Kota Maros.

Kegiatan ini merupakan usaha untuk mengontrol jumlah dan jarak antara kelahiran anak $\mathrm{KB}$ artinya mengatur jumlah anak sesuai kehendak menentukan sendir kapan ingin hamil, dan merupakan sebuah program pemerintah dengan pengaturan jumlah dan jarak anak untuk menuju keluarga berkualitas. Subyek pelatihan adalah pasangan usia subur yang berada diwilayah kerja Desa Laeng-Laeng Wilayah Puskesmas Bantimurung Kota Makassar.

\section{Survey dan Analisis}

Masalah Survei dan analisis masalah merupakan langkah awal yang dilakukan untuk mengetahui permasalahan atau kendala yang dialami pasangan usia subur di Leang-Leang dalam sosialisasi KB. Pada umumnya pasangan wanita usia subur kesulitan menemukan materi tentang keluarga berencana. Hal ini menyebabkan banyak pasangan wanita usia subur tidak menggunakan alat kontrasepsi.

\section{Perumusan Masalah dan Pengembangan Solusi}

Berdasarkan hasil analisis masalah dapat disumpulkan bahwa pasangan wanita usia subur masih belum mengetahui tentang keluarga berencana. Solusi yang diberikan yaitu sosialisasi tentang penyuluhan keluarga berencana. Pelaksanaan pengabdian ini berupa sosialisasi yang dilakukan dengan menggunakan metode ceramah, diskusi dan tanya jawab.

\section{HASIL DAN PEMBAHASAN}

Pelaksanaan pengabdian pada pasangan wanita usia subur Di Desa Laeng-Laeng Puskesmas Bantimurung. Pemberian penyuluhan dilaksanakan pada tanggal 07 November 2017 pukul 09.00-selesai. Dalam penyuluhan pemberian materi Keluarga Berencana.

Bentuk kegiatan dibagi menjadi 2 tahap, meliputi: Acara Ceremonial Pembukaan yang terdiri sambutan dari pihak institusi dalam hal ini Ketua Prodi dan Kepala Kelurahan. Acara kedua yaitu materi, konseling dan pemasangan IUD. Penyuluhan tentang upaya menurunkan Angka Kematian ibu melalui peningkatan kesehatan ibu hamil dan kesehatan reproduksi yang terdiri dari 3 susunan materi sebagai berikut.

\section{Penyuluhan Materi I}

Keluarga berencana adalah upaya mengatur kelahiran anak, jarak dan usia ideal melahirkan, mengatur kehamilan, melalui promosi, perlindungan, dan bantuan sesuai dengan hak reproduksi untuk mewujudkan keluarga yang berkualitas.

\section{Penyuluhan Materi II}

Kontrasepsi adalah metode atau alat yang digunakan untuk mencegah kehamilan. Ada berbagai jenis kontrasepsi, masing-masing dengan manfaat dan kekurangannya masing-masing. Sebagian KB dianggap membuat tubuh gemuk, 
sehingga banyak wanita yang enggan menggunakan jenis KB tersebut

\section{Penyuluhan Materi III}

Pada materi ini disampaikan hal-hal terkait dengan 1) Pil KB, 2) Suntik KB, 3) Susuk KB atau implant, 4) Intra Uterine System (IUS), 5) Kondom, 6) Intra Uterine Device (IUD) 7) Metode sederhana atau vaginal Bagi wanita, 8) Tubektomi 9) Vasektomi 10) Sistem KB kalender 11) Pada ibu yang menyusui secara eksklusif.

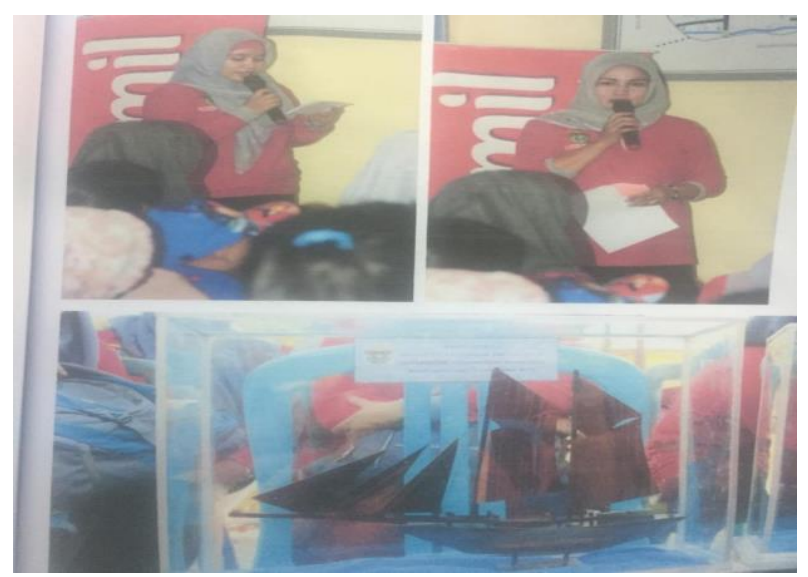

Gambar 1. Kegiatan Pembukaan

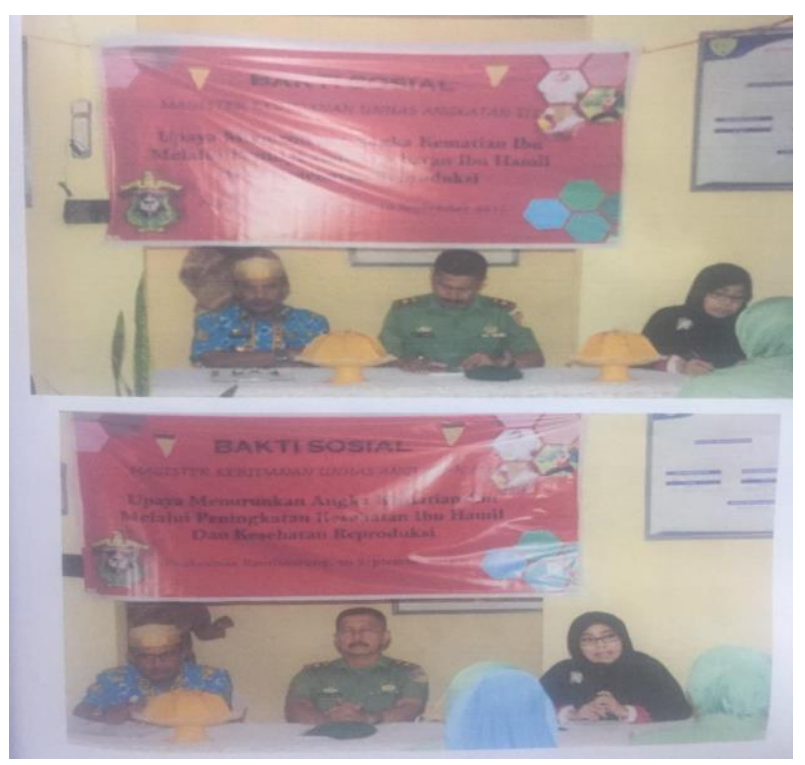

Gambar 2. Materi Penyuluhan oleh Narasumber
Setelah materi, kegiatan dilanjutkan dengan kegiatan konseling tentang Keluarga Berencana dan kegiatan terakhir adalah Pemasangan IUD oleh bidan Puskesmas.

\section{Evaluasi Peningkatan Pengetahuan}

Kegiatan yang dilakukan ini memberikan manfaat peningkatan pengetahuan ibu hamil dan pasangan usia subur dalam bidang keluarga berencana melalui materi dan kegiatan konseling. Selain itu, masyarakat mendapatkan layanan kontrasepsi gratis melalui pemasangan IUD yang dilakukan oleh pikah puskesmas yang merupakan mitra pada kegiatan ini. Hal ini sesuai dengan tujuan dilaksanakannya kegiatan sebagai upaya meningkatkan kesehatan ibu untuk mengurangi angka kematian.

\section{SIMPULAN}

Kegiatan memberikan hasil sesuai dengan tujuan kegiatan yaitu melalui kerjasama antara pihan institusi kampus dan pemerintah desa. Kegiatan yang terdiri dua rangkaian kegiatan ini memberikan hasil peningkatan pengetahuan dan mendapatkan layanan kontrasepsi IUD gratis bagi masyarakat. Hasil kegiatan ini diharapkan dapat menjadi upaya untuk mengurangi angka kematian ibu karena persalinan yang diakibatkan oleh jarak kelahiran yang terlalu dekat.

\section{UCAPAN TERIMA KASIH}

Kegiatan pengabdian ini didanai oleh Direktorat Jenderal Pembelajaran dan Kemahasiswaan Kementerian Pendidikan dan Kebudayaan Republik Indonesia. 


\section{DAFTAR PUSTAKA}

Ambarwati, E. R., Khoirunnisa, E., \& -, W. (2016). Health Promotion Model to Increase Maternal Visit and Exclusive Breastfeeding in the Puerperium Period in Sleman, Yogyakarta. Journal of Health Promotion and Behavior, 01(03), 138-148.

Desa, B. (2016). Model Kelas Ibu Hamil Untuk Pemetaan Risiko Kehamilan Dan Pencegahan Komplikasi Persalinan. Jurnal Abdimas, 20(1), 11-18.

Nurjasmi, E. (2020). Situasi Pelayanan Kebidanan pada Masa Pandemi COVID-19. Ibi.or.Id, 132. Retrieved from https://www.ibi.or.id/id/article_view/A20200 611001/unduh-materi-webinar-ibi-usaidjalin-seri-5-10-juni-2020.html

Sri, H., \& Mubarokah, K. (2018). HIGEIA JOURNAL OF PUBLIC HEALTH RESEARCH AND DEVELOPMENT Kondisi Demografi Ibu dan Suami pada Kasus Kematian Ibu. Higeia Journal of Public Health Research and Development, 3(5), 99-108. Retrieved from http://journal.unnes.ac.id/sju/index.php/higei a

Yuningsih, R. (2016). Midwifery Profession In Policy Development Efforts To Improve Maternal and Child Health Services Rahmi. Center for Expertise Research DPR RI, 7(1), 63-76. 